\title{
THE NATURE OF TOXIN
}

\section{THE ANTIGENS OF CORYNEBACTERIUM DIPHTHERIAE AND BACILLUS MEGATHERIUM AND THEIR RELATION TO TOXIN}

\author{
C. C. WARDEN, J. T. CONNELL AND L. E. HOLLY \\ Ann Arbor, Michigan
}

Received for publication July 20, 1920

Previous work upon a considerable number of bacteria and other types of living cells having demonstrated that each variety of cell possesses a fat complex which is specifically antigenic, ${ }^{1}$ it was determined to ascertain whether toxin-producing bacteria might not also yield fat antigen complexes, and whether such antigens bear any relationship to the toxins.

For this purpose we selected $C$. diphtheriae and the $B$. megatherium, both of which yield heavy growths as well as produce abundant toxin in suitable media. It has seemed advisable for purposes of explanation and comparison to include the observations upon both of these bacteria in one paper. The toxin of $C$. diphtheriae induces strong antitoxin, but the antigen of the organisms themselves is not conspicuous in the production of other immune substances such as agglutinins, precipitins and complement fixing bodies, while on the other hand the $B$. megatherium gives rise to abundant antibodies of such nature together with antihemolysins and antitoxins. Where the reactions of these two organisms have characters in common they tend to confirm one another, and the deficiences of one may be explained by the data obtained from the other. Moreover, the work on these bacteria was carried on at the same time, together with that of Connell and Holly on the "Nature of Hemolysins."

\footnotetext{
${ }^{1}$ Warden, Jour. Infect. Dis., 1918, 22, 133; ibid., 1918, 23, 504; ibid., 1919, 24, 285; Warden and Connell, ibid., 1919, 25, 399.
} 


\section{DIPHTHERIAE. THE ANTIGEN}

The strain of organism used was the Park no. 8. The cultures were prepared in a manner calculated to produce the greatest luxuriance of growth and the maximum of toxin. For these purposes there was used veal infusion to which were added 2 per cent pepton and $\mathbf{0 . 5}$ per cent $\mathrm{NaCl}$. The pepton was for the most part a "proteose" pepton prepared by the Digestive Ferments Company which was found to yield toxin of high grade. The proteose broth was adjusted to a $\mathrm{pH}$ of 7.9 with $\mathrm{NaOH}$ prior to autoclaving. The organisms were trained to rapid pellicle formation by frequent transplantations before the final inoculations upon large surfaces of the nutrient broth as recommended by Bunker ${ }^{2}$ which were made upon shallow depths of broth in Roux flasks laid on the flat and slightly inclined, giving an area of 40 square inches per flask and a depth varying from $\frac{3}{4}$ to $1 \frac{1}{2}$ inches. Good pellicles covered the surfaces in twelve hours, and the growths were maintained at $35^{\circ} \mathrm{C}$. for five to six days. It was essential that the medium should be as nearly fat-free as possible, and accordingly every precaution was taken in that regard. Careful siphonage and filtration while the broth was strongly acid, that is before the addition of alkali, with strict attention to cleanliness of vessels and glassware insured a medium containing a negligible amount of fat.

At the conclusion of the incubation period the toxic broth was separated from the germ mass by filtration through paper. The germ residues were then examined for fat content by methods described in earlier articles. The total moist residue, a portion of which was kindly supplied by Dr. Clark of the laboratory of Parke, Davis and Company, used in the examination weighed over $1 \mathrm{kgm}$. The fatty acid complex obtained therefrom was found to consist of approximately 80 per cent of unsaturated acids, and 20 per cent of saturated, nonvolatile acids.

The toxin broth filtrates to the amount of 50 liters were also examined and found to contain the same fat complex in quantities averaging 60 to $80 \mathrm{mgm}$. per liter, an amount equal to about two-thirds of that obtained from the germ residue from

2 Jour. Bact., 1919, 4, 4. 
1 liter. The addition of cresols or other similar preservatives to the cultures renders the toxin filtrates unfit for examination, and the germ residues must be freed from it before accurate examination of the fats can be made. The cresols pass unchanged into the solvents along with the fatty acids, making their purification difficult and wasteful. A trace of cresol renders an iodin determination fallacious because of the formation of additive compounds with the halogen in Hübl's solution.

Having determined approximately the composition of the fatty acid complex derived from the germ bodies and toxin broth, this complex was then tested against the serums of immunized animals - it being the custom to check the tentative analysis in this manner. Knowing the complex to contain about 80 per cent of unsaturated fatty acid corresponding closely in its various values to an oleic acid, and about 20 per cent of lower, non-volatile saturated acids having a calculated M.W. of 250, and melting point of $58^{\circ} \mathrm{C}$, , several trial artificial antigen complexes were prepared, having approximately the same values, from the purest obtainable fatty acids procured from sources other than the germ bodies. These artificial antigens were: No. 1, oleic acid 80 per cent, palmitic acid 16 per cent, myristic acid 4 per cent. - No. 2 , oleic acid 83.3 per cent, palmitic acid 16.7 per cent. No. 3 , oleic acid 84 per cent, stearic acid 16 per cent. (The specimen of oleic acid used. was the normal acid, having an I. V of 87.5). They were prepared for testing by combining the $\mathrm{Na}$ salts of the acids in the above proportions in alcoholic solution in such weights that $1 \mathrm{cc}$. contained $2 \mathrm{mgm}$. of the complex, and to each 5 parts of the solution there was added 4 parts of a 1 per cent alcoholic solution of cholesterol, the latter being employed to furnish an adsorption surface for the antigen proper.

Experiments in complement fixation were then made with the serums of rabbits that had been immunized, some with washed $C$. diphtheriae germ bodies, others with toxin. Three separate tests were made with the serums of two groups of animals, using the sheep-rabbit hemolytic system, fresh guinea-pig complement, and a control antigen suspension in salt solution of thoroughly washed diphtheria bacilli from a twenty-four hour broth 
culture. The antigenic titer of the control antigen was 0.04 cc. and that of the artificial antigens 0.1 cc. of emulsions made by mixing 1 cc. of the alcoholic antigen solutions with $16.5 \mathrm{cc}$. of salt solution. Two units of amboceptor and 2 units of complement were used, and 0.5 cc. of a 2 per cent washed sheep cell suspension, all tubes being brought to a volume of 1 cc. with salt solution. The first incubation was for thirty minutes at $37^{\circ} \mathrm{C}$., the second for one hour followed by standing at $20^{\circ} \mathrm{C}$. for several hours. The serums of control and immunized rabbits were inactivated at $56^{\circ} \mathrm{C}$. for thirty minutes. The results of the tests are shown in tables 1,2 and 3.

TABLE 1

First group of rabbits

\begin{tabular}{|c|c|c|c|c|c|}
\hline \multirow[b]{2}{*}{ SERUMS } & \multicolumn{5}{|c|}{ ANTIGENA } \\
\hline & $\begin{array}{l}\text { Control } \\
\text { germ } \\
\text { suspen- } \\
\text { sion }\end{array}$ & No. 1 & No. 2 & No. 3 & $\begin{array}{l}\text { Control } \\
\text { anthrax } \\
\text { antigen }\end{array}$ \\
\hline 1. Rabbit injected organisms...... & ++ & ++ & $+t$ & ++ & \pm \\
\hline 2. Rabbit injected organisms...... & $+t$ & $+t$ & $+t$ & ++ & + \\
\hline 3. Rabbit injected toxin... ...... & ++ & ++ & ++ & ++ & ++ \\
\hline 4. Rabbit injected toxin.......... & $+t$ & ++ & $+t$ & ++ & \pm \\
\hline 5. Normal horse............... & - & - & - & ++ & - \\
\hline 6. Normal rabbit............... & - & + & - & ++ & ++ \\
\hline 7. Normal horse................ & + & + & \pm & ++ & - \\
\hline 8. Control, no serum............ & - & - & - & - & - \\
\hline
\end{tabular}

TABLE 2

Second test of first group, following fresh bleeding two days later

\begin{tabular}{c|c|c|c|c|c}
\hline & \multicolumn{5}{|c}{ ANTIGENs } \\
\cline { 2 - 6 } sERums & $\begin{array}{c}\text { Control } \\
\text { germ } \\
\text { suspension }\end{array}$ & No. 1 & No. 2 & No. 3 & $\begin{array}{c}\text { Control } \\
\text { Streptoco- } \\
\text { cus antigen }\end{array}$ \\
\hline 1 & ++ & + & ++ & - & + \\
2 & ++ & + & ++ & \pm & - \\
3 & ++ & + & ++ & ++ & - \\
4 & ++ & + & ++ & ++ & - \\
5 & - & \pm & - & - & + \\
6 & - & - & - & + & + \\
7 & ++ & - & ++ & ++ & ++ \\
Control, no serum....... & - & - & - & - & - \\
\hline
\end{tabular}




\begin{tabular}{|c|c|c|c|c|}
\hline \multirow[b]{2}{*}{ SERUMS } & \multicolumn{4}{|c|}{ ANTIGENS } \\
\hline & $\begin{array}{l}\text { Control } \\
\text { germ } \\
\text { suspen- } \\
\text { sion }\end{array}$ & No. 1 & No. 2 & No. 3 \\
\hline 1. Rabbit injected organisms............ & + & ++ & + & + \\
\hline 2. Rabbit injected organisms............ & + & + & + & + \\
\hline 3. Rabbit injected organisms..... & ++ & ++ & ++ & + \\
\hline 4. Rabbit injected toxin......... & - & - & - & - \\
\hline 5. Rabbit injected toxin....... & + & \pm & + & ++ \\
\hline 6. Normal rabbit............. & - & - & - & - \\
\hline 7. Control, no serum................ & - & - & - & - \\
\hline
\end{tabular}

In tables 1,2 , and $3,++=$ no hemolysis, complete inhibition; $+=$ partial hemolysis; $-=$ complete hemolysis, no inhibition.

From these tests it appeared that artificial antigen no. 2 gave results in closest agreement with the control diphtheria germ suspension antigen. It was accordingly employed in the succeeding work. We do not agree with the statement of $\mathrm{A}$. Besson $^{3}$ to the effect that animals immunized with toxin show no immune bodies in their serums.

Agglutination and precipitation experiments were not made with these serums or this antigen, nor was any attempt made, for reasons mentioned earlier, to immunize animals with the artificial antigen, such reactions being shown better with the B. megatherium.

\section{THE NATURE OF DIPHTHERIA TOXIN}

The toxic broth as it comes from the filters is alkaline, having a $\mathrm{pH}$ varying from 8.0 to 8.33. An experiment of Connell's showed that the increased alkalinity might be due to the ammonia, of which there was found $34 \mathrm{mgm}$. against $14 \mathrm{mgm}$. in fresh broth. We had also shown that, among other changes, the broth had become richer in fats, or salts of fatty acids, and that these corresponded with those obtained from the bodies of the germs themselves.

3 Pract. Bact., 1913, p. 269. 
We assume there can be no question that diphtheria toxin is diphtheria antigen since its injection into animals produces a specific antitoxin which unites with no other known antigen. The concensus of opinion is that toxin is not a protein and does not require protein for its development. ${ }^{4}$ If we accept, then, as one postulate the statement that toxin is specific antigen, and as another that the specific fat complexes of cells constitute their antigens, it follows that diphtheria toxin must be composed of the diphtheria fat complex in one form or another, and it should be possible to demonstrate the correctness or falsity of our assumption by means of the artificial fat antigen in a certain colloidal state.

In taking up this work we planned to commence with a broth menstruum known to yield good toxin, and to combine with it varying proportions of the fat antigen in various forms. Accordingly a standard broth identical with that used for actual toxin production was adopted. Artificial antigen no. 2 was prepared in proper proportions in the forms of the fatty acids, the alkali salts, Na and $\mathrm{K}$, the ethyl esters, and the glyceryl and cholesteryl esters. The ammonium salts were too unstable for use since in presence of Na ions in excess the $\mathrm{NH}_{4}$ ions are replaced. Cholesterol was omitted from these antigens:

We regarded the broth as a highly complex colloidal fluid containing proteoses existing as particles of varying colloidal dimensions, as shown by ultrafiltration ${ }^{5}$ unknown organic matter from the veal infusion, coloring matter, and various electrolytes in addition to $\mathrm{NaCl}$, all under the influence of a primary $\mathrm{pH}$ of 7.9. We assumed that the diphtheria bacilli, trained to the most rapid reproduction on the most favorable medium must also die and disintegrate rapidly according to a general principle of life and death, ${ }^{6}$ liberating their fat complex in an emulsified or

4 Jordan, Genl. Bact., 1918, p. 266; Guinochet, Arch. de Med. exp., 1892, 4, 487; Hadley, Jour. Infec. Dis., 1907, Suppl. 3, p. 95.

5 Bechhold-Bullowa, Colloids in Biol. and Med., 1919, p. 99.

'Vesilova, Russk. Vrach., 1915, 9, 205; Park and Williams, Pathol. Microorg., 1920 , p. 343. As an adjunct to the "life and death" principle in accounting for the death of microorganisms, in fluid cultures at a time when the quantity of lysin or toxin is at a maximum, is the fact of the existence in the fluid of the 
colloidal form, which then, by reason of the necessity for such surface-tension-lowering substances to collect at the interfaces between dispersed and watery phases, become adsorbed upon colloidal particles of a certain size in the broth, forming, with electrolyte, an adsorption entity constituting toxin. We do not believe there is any evidence whatever to show that toxin exists preformed within the bodies of the bacilli and passes through their membranes into the culture medium. The particles of the toxic adsorption aggregate must be very small as we know from the ultrafiltration experiments of Bechhold ${ }^{7}$ being slightly larger than protalbumoses and smaller than the particles in 1 per cent hemoglobin solution. We realized the impossibility of reproducing artificially all the changes undergone by medium and bacteria during the life of the culture, but we tried to imitate as closely as might be the processes of colloidal nature which we assumed on good evidence to take place.

The various methods used may be mentioned here: (a) The fatty acid antigen in varying doses, in ether solution, was overlaid on the surface of $100 \mathrm{cc}$. of broth in Erlenmeyer flasks of 250 cc. capacity. This was soon abandoned. (b) The fatty acids were floated in bulk on the broth surface. This method was also unavailable. (c) The fatty acids in alcoholic solution were pipetted upon the surface of the medium, and also emulsified by mixing at once. (d) The same methods were used with the $\mathrm{K}$ and $\mathrm{Na}$ salts, and with the ethylic, glyceryl and cholesteryl esters. Several flasks of each description were always made so as to permit of daily examination. All the operations were carried out in a sterile manner. Departures were made from the standard medium to include veal infusion without peptone, peptone solutions alone, and, finally, to eliminate all protein, colloids of mastic-fat in water and salt solution.

fatty acids, or their salts, derived from the bacteria, in just such amounts as inhibit the growth of the germs, and at the same time cause the lysis of cells. Itois significant that the dose of the $\mathrm{Na}$ salts of the anthrax antigen just sufficient to prevent the development in broth of the bacilli from spores, $60 \mathrm{mgm}$. per liter, is that which toxic and lytic broths were found to contain, and approximately that which was added of the alkali salts to the artificial lysins and toxins, as will be shown later.

7 Loc. cit. 
The alcoholic solutions of the antigen fatty acids, salts and esters were sterile and of convenient strengths for the pipetting of small amounts to the broth with the minimum of alcohol. Control experiments showed that the addition of corresponding quantities of alcohol alone gave rise to no precipitation or other appreciable change. The antigens were added in weights varying from $1 \mathrm{mgm}$. per $100 \mathrm{cc}$. to $20 \mathrm{mgm}$. per $100 \mathrm{cc}$. in a maximum of 1 cc. of alcohol, without material change in the $\mathrm{pH}$ either at once or with the passage of time. After inoculation the flasks were placed, without stirring, save where emulsification was done at once, in the incubator at $35^{\circ}$ to $37^{\circ} \mathrm{C}$. where they remained undisturbed until examined. The $\mathrm{pH}$ of the broth was also made to vary from the standard so as to try the effects of such concentrations as 7.38, 8.0, 8.1 and 8.33. Some of the flasks were made alkaline to the lower figures by ammonia added in a sterile manner after autoclaving and cooling. Several flasks were incubated under lowered oxygen tension. When a flask was removed from the incubator the $\mathrm{pH}$ of the contents was taken, and the degree of clearness noted, as well as the presence or absence of sediment and of faint scum of unemulsified fat upon the surface. As a rule 2 cc. quantities taken from the center of the fluid were then injected subcutaneously into guinea pigs averaging 275 grams weight.

The results of these experiments are shown in tables 4 and 5 .

TABLE 4

\begin{tabular}{|c|c|c|}
\hline FATTYY ACIDS & $\begin{array}{c}\text { TOTAL } \\
\text { GUINEA } \\
\text { PIGS } \\
\text { INJEGTED }\end{array}$ & DIED \\
\hline 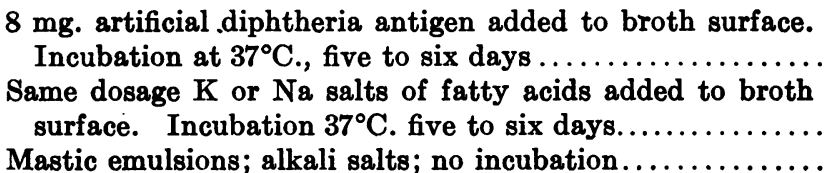 & $\begin{array}{l}82 \\
15 \\
25\end{array}$ & $\begin{array}{l}79 \\
11 \\
20\end{array}$ \\
\hline
\end{tabular}

Number of pigs dying in 1 to 4 days..................... 21

Number of pigs dying in 5 to 14 days................... 50

Number of pigs dying in 14 to 30 days................. 29 
TABLE 5

Showing a specimen portion of the death record in greater detail

\begin{tabular}{|c|c|c|c|c|c|c|}
\hline pH. & 7.3 & 7.6 & 7.8 & 7.9 & 8.04 & 8.3 \\
\hline Deaths... & 0 & 2 & 1 & 9 & 4 & 1 \\
\hline Alcoholic solution fatty acids: & & & & & & \\
\hline Incubation (days) .......... & 2 & 3 & 4 & $\mathbf{5}$ & 6 & $8-12$ \\
\hline Deaths................. & 1 & 3 & 1 & 8 & 2 & 4 \\
\hline Days to kill........ & 1 & 2 & 3 & 4 & $5-10$ & $10-14$ \\
\hline Deaths. $\ldots \ldots \ldots \ldots \ldots \ldots \ldots \ldots \ldots$ & 3 & 3 & 2 & 4 & 4 & 4 \\
\hline
\end{tabular}

There were included in these tables only those animals dying without infection which presented at autopsy a definite picture of the macroscopic lesions characteristic of death from diphtheria toxin, viz., great emaciation, hemorrhages into the capsules of the adrenals and kidneys, enlarged and hemorrhagic kidneys, injection and hemorrhage of the lungs. Free fluid in the pleural sacs and intestinal injection were variable signs. The best results were obtained from dark colored broth inoculated on the surface with $8 \mathrm{mgm}$. of the fatty acid antigen and allowed to remain at $37^{\circ} \mathrm{C}$. for five to six days, and which, at the time of injection was clear, or with a fine colloidal haze, had a $\mathrm{pH}$ of 7.9 to 8.1, a very slight or no surface pellicle and a slight sediment consisting for the most part of crystalline phosphates. Nearly all animals injected with such broth died. Filtration through a Berkefeld filter greatly diminished the toxicity. Distinctly cloudy fluids did not give good results. The antigen in the form of the $\mathrm{K}$ salts gave good results, while no deaths at all were obtained from the broth containing the ethyl, glyceryl or cholesteryl esters. We found that with the same broth inoculated with the same dose of antigen, in the same manner so far as control was possible, there were obtained fluids of many degrees of emulsification from clearness to dense cloudiness. The reason for this in the absence of contamination was not apparent. We had difficulty also in making different lots of broth alike, particularly in color, some being pale, others dark, depending somewhat on the quality of the veal used for making the infusion. 
A notable feature of the results was the irregularity in killing time. Not infrequently a toxic broth which killed one guineapig in two days did not kill the other of the pair until much later. We attempted to account for this peculiar result by recognizing the extreme instability of such colloids, the slightly different conditions encountered in the tissues of the various guinea-pigs sufficing to alter the physical state of the injected fluid.

Control guinea-pigs that died following injection of Streptococcus and of Pneumococcus artificial antigen broth showed pulmonary congestion and hemorrhages without particular damage to kidneys or adrenals.

The most serviceable colloids of mastic were found, after many trials, to be those prepared by adding to an alcoholic solution of mastic of known concentration the desired amount of alcoholic solution of fat antigen, and then emulsifying in sterile water or salt solution by adding the alcoholic mixture to the fluid kept in constant whirling motion. The emulsions were pale white with orange colors by reflected light, and the particles were beyond the limits of microscopic vision. The clearest results were obtained with colloids containing $5 \mathrm{mgm}$. of mastic and 5 to $8 \mathrm{mgm}$. of the $\mathrm{K}$ salt antigen in $100 \mathrm{cc}$. of diluent, and brought to a $\mathrm{pH}$ of $7.9-8.0$ with $\mathrm{NaOH}$. On standing the $\mathrm{pH}$ shifts to the acid side. The injections were made with freshly prepared sterile emulsions.

The pathological picture exhibited in guinea-pigs dying from diphtheria and artificial toxin, while characteristic, presents certain features which in the long run do not appear to be distinctive of that poison alone. Out of the control animals in number at least equal to the determinants and kept under the same conditions, there were found two pigs dead following injections of supposedly tuberculous urine showing hemorrhages into the adrenals, and one apparently normal pig, without infection, showing the same lesion. The kidneys of these animals were not noticeably affected. These three control guineapigs were the only examples however, in this and in previous work upon fat antigens, in which lesions in any way similar to those of diphtheria toxin were observed. 
The diphtheria fatty acid-colloidal fluids used for injection were not hemolytic for rabbit cells in the test tube, whereas those prepared with the $\mathrm{K}$ salts were strongly so. Vesilloff ${ }^{8}$ showed that the bacilli from very young broth cultures removed by centrifugation and suspended in salt solution were hemolytic. Lubenau $^{9}$ states that broth cultures are hemolytic between the second and fourteenth days, varying with different strains.

In seeking an explanation for the instability of our artificial toxic colloids we were reminded of the fact that the methods of emulsification so far employed must be of the crudest nature compared with those which accompany the disintegration of the bacilli. We regard the cells, bacterial or other, as consisting of emulsion colloids of water, protein, fat, salts, etc., having at their surfaces or limiting layers an excess of those substances which lower surface tension and aid in regulating permeability, and which, according to the principle of Willard Gibbs must exist at the surfaces, namely emulsified fats, their acids and salts, and protein. The colloidal state of the limiting surfaces is probably different from that within the cells-a reversed type of colloid like a water-in-oil emulsion, in contrast to an oil-inwater emulsion to which one may compare the state of the interior of the cells..$^{10}$ Cells disintegrating or autolyzing in a watery colloidal menstruum such as broth possess dispersion means of remarkable power owing to the highly emulsified state of the fats which, liberated under such conditions, must pass to interfaces in the fluid in a manner far more delicate than we can readily approach in an artificial way. With these ideas in mind we believed we should be able to obtain greater stability in the artificial toxins if we emulsified the fat antigen prior to adding it to the broth. Accordingly we combined the antigen with solutions of the commoner proteins at hand such as hemoglobin, casein, egg albumen, gelatin, and a protein derived from the Bact. typhosum, substituting the alkali salts of the antigen for the fatty acids because of their somewhat greater emulsifying

${ }^{8}$ Russk. Vrach., 1913, October 13, p. 235.

- Centr. f. Bakt., 1901, 30, 365.

${ }^{10}$ Clowes, Science, 1916, 43, 750-757. 
properties. The colloids formed in this manner were of great interest. If to a solution of $10 \mathrm{mgm}$. of hemoglobin in 5 cc. of salt solution there was added drop by drop the alcoholic antigen solution a somewhat opalescent colloid resulted. When this mixture was added to the standard broth in constant motion drop by drop there resulted beautifully clear, stable liquids even when the amount of fat antigen exceeded $200 \mathrm{mgm}$. per 1 liter. When, however, the hemoglobin solution alone, or the hemoglobin-antigen solution was added to the broth all at once, instead of gradually, the resulting fluids became cloudy. The same results were noted with fat-free casein-antigen and the typhoid protein-antigen mixtures. The emulsions made with fresh egg white and with gelatin were never perfectly clear.

Of particular interest were the colloids made with the typhoid protein-antigen emulsions. The typhoid protein itself, of which mention has been made in an earlier paper, is soluble in salt solution, non coagulable by heat, contains but traces of amino nitrogen and is highly toxic for laboratory animals in small doses. It is toxic also when its solution is mixed with broth by the drop method, 1 cc. of the fluid containing $0.25 \mathrm{mgm}$. injected intraperitoneally into guinea-pigs being fatal in twentyfour hours. On the other hand twice the dose produces no symptoms at all if the protein solution be added to the broth all at one time. The addition of the fat antigen to the colloid increases the toxicity, and gives to the autopsy picture its distinctive character. Guinea-pigs dying from the effects of the protein alone present no signs beyond slight injection of the visceral and parietal peritoneum whereas those dying from the protein antigen emulsions show characteristic signs of diphtheria toxin poisoning. We do not believe that the typhoid protein, derived as it is from the germ bodies that have undergone prolonged defatting extractions with alcohol and with ether, represents the proper protein of the bacteria during life, but this view does not militate against the conception that the proteins of some microörganisms liberated by autolysis in fluids may also be somewhat toxic if emulsion in a proper colloidal state occurs. We are inclined to the belief that the potentialities for toxin 
production are always present when bacteria are permitted to undergo lysis in fluid culture media, and that actual toxin production depends first on the characters of the emulsified fat antigen complex and second upon its colloidal arrangement.

The mixtures of hemoglobin and broth, and of casein and broth did not show toxicity whereas these emulsions containing the fat antigen were toxic.

Still another factor instrumental in the making of suitable protein-antigen broth colloids is that of the color of the broth. The pigment of broth appears to be a distinct aid to emulsification. Very light colored broth is a much poorer colloidal medium than one which is dark. Besredka11 noted that the filtrates of his streptococcus lysin which had lost some of the color during the filtration were impaired in hemolytic power. Connell and Holly showed that a broth which had been passed through a Berkefeld filter prior to the addition of artificial megatherium antigen had practically lost its hemolytic power as compared with the unfiltered broth containing the antigen. Very slight alterations in broth lead to great colloidal changes.

A very important factor also is the maturation of the proteinfat antigen-broth colloids. A period of time of at least one hour at $20^{\circ} \mathrm{C}$. after the mixing of the ingredients is essential to the development of maximum hemolytic and toxic power, after which time, at $4^{\circ} \mathrm{C}$. the activity remains stationary for a considerable period and then gradually declines. Heat inactivates these mixtures in a manner similar to true hemolysin and toxins.

The toxicity of the artificial fat-protein colloids is shown in the specimen protocol given in table 6. All the injections were

TABLE 6

Artificial colloid no. 1: 35 cc. of standard broth to which was added in divided doses $10 \mathrm{mgm}$. of typhoid protein dissolved in $5 \mathrm{cc}$. salt solution.

Artificial colloid no. 2 : The same, to which the protein solution was added in a single dose.

Artificial colloid no. 3: The same, to which was added in divided doses 5 cc. of a salt solution emulsion of $10 \mathrm{mgm}$. of typhoid protein with $4.8 \mathrm{mgm}$. of $\mathrm{K}$ salt diphtheria antigen.

Artificial colloid No. $3 A$ : The same, with $5 \mathrm{mgm}$. of typhoid protein.

11 Ann. de l'Inst. Past., 1901, 16, 880. 


\section{TABLE 6-Continued}

Artificial colloid no. 4: 35 cc. of standard broth to which was added in divided doses 5 cc. of a salt solution emulsion containing $10 \mathrm{mgm}$. of fat-free casein and $4.8 \mathrm{mgm}$. of $\mathrm{K}$ salt antigen.

Artificial colloid no. 5: The same, with $10 \mathrm{mgm}$. of hemoglobin substituted for the casein.

Artificial colloid no. 6: The same, with $10 \mathrm{mgm}$. of gelatin substituted for the hemoglobin.

Artificial colloid no. 7: The same, using $100 \mathrm{mgm}$. of fresh egg white as protein.

\begin{tabular}{c|c} 
GUINEA \\
PIG \\
NUMBER
\end{tabular}$\left|\begin{array}{c}\text { AMOUNT } \\
\text { INJECTED } \\
\text { INTRA- } \\
\text { PERTONE- } \\
\text { ALLY }\end{array}\right| \cdots$

Guinea-pigs injected with colloid no. 1

\begin{tabular}{l|l|l}
\hline 1 & 2.0 & Died in 12 hours, intestines hemorrhagic \\
2 & 2.0 & Died in 4 hours, intestines hemorrhagic \\
3 & 1.0 & Died in 4 hours, intestines hemorrhagic \\
4 & 0.5 & Lived \\
5 & 0.25 & Lived \\
\hline
\end{tabular}

Guinea-pigs injected with colloid no. 2

\begin{tabular}{l|l|l}
\hline 6 & 2.0 & No symptoms \\
7 & 1.0 & No symptoms \\
8 & 0.5 & No symptoms \\
\hline
\end{tabular}

Guinea-pigs injected with colloid no. 3

\begin{tabular}{|c|c|c|}
\hline 9 & 2.0 & Died $4 \frac{1}{2}$ hours; typical lesions \\
\hline 10 & 2.0 & Died 5 hours; typical lesions \\
\hline 11 & 2.0 & Died $3 \frac{1}{2}$ hours; typical lesions \\
\hline 12 & 2.0 & Died 7 hours; typical lesions \\
\hline 13 & 2.0 & Died 6 hours; typical lesions \\
\hline 14 & 1.0 & Died 7 hours; typical lesions \\
\hline 15 & 0.5 & Died 15 days \\
\hline 16 & 0.5 & Lived \\
\hline 17 & $1.0^{*}$ & Lived \\
\hline 18 & $1.0^{*}$ & Lived \\
\hline 19 & $2.0 \dagger$ & Lived \\
\hline 20 & $2.0 \dagger$ & Lived \\
\hline 21 & $2.0 \dagger$ & Lived \\
\hline
\end{tabular}

* Plus 250 units antitoxin.

$\dagger$ Plus 500 units antitoxin. 
THE NATURE OF TOXIN

TABLE 6-Concluded

\begin{tabular}{|c|c|c|}
\hline 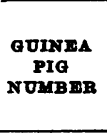 & 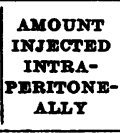 & BESUUTS \\
\hline \multicolumn{3}{|r|}{ Guinea-pigs injected with colloid $3 a$} \\
\hline $\begin{array}{l}22 \\
23\end{array}$ & $\begin{array}{l}2.0 \\
2.0\end{array}$ & $\begin{array}{l}\text { Died second day; typical lesions } \\
\text { Died third day; typical lesions }\end{array}$ \\
\hline \multicolumn{3}{|r|}{ Guinea-pigs injected with colloid 4} \\
\hline $\begin{array}{l}24 \\
25 \\
26 \\
27\end{array}$ & $\begin{array}{l}2.0 \\
2.0 \\
1.00^{*} \\
1.00^{*}\end{array}$ & $\begin{array}{l}\text { Died third day; typical lesions } \\
\text { Died fourth day; typical lesions } \\
\text { Died seventh day; fair lesions } \\
\text { Died seventh day; fair lesions }\end{array}$ \\
\hline \multicolumn{3}{|r|}{ Guinea-pigs injected with colloid 5} \\
\hline $\begin{array}{l}28 \\
29 \\
30 \\
31\end{array}$ & $\begin{array}{l}2.0 \\
2.0 \\
2.0 \\
2.0\end{array}$ & $\begin{array}{l}\text { Died third day; typical lesions } \\
\text { Died first day; typical lesions } \\
\text { Died fifth day; fair lesions } \\
\text { Died tenth day; typical lesions }\end{array}$ \\
\hline \multicolumn{3}{|r|}{ Guinea-pigs injected with colloid 6} \\
\hline $\begin{array}{l}33 \\
33\end{array}$ & $\begin{array}{l}2.0 \\
2.0\end{array}$ & $\begin{array}{l}\text { Died second day; good lesions } \\
\text { Lived }\end{array}$ \\
\hline \multicolumn{3}{|r|}{ Guinea-pigs injected with colloid 7} \\
\hline $\begin{array}{l}34 \\
35\end{array}$ & $\begin{array}{l}2.0 \\
2.0\end{array}$ & $\begin{array}{l}\text { Lived } \\
\text { Lived }\end{array}$ \\
\hline
\end{tabular}

made intraperitoneally into guinea-pigs of 250 grams average weight. The autopsies showed the characteristic lesions. All the colloidal fluids were matured for one and one-half hours at $20^{\circ} \mathrm{C}$.

The neutralizing action of antitoxin upon artificial toxin is indicated in the foregoing table. The dose of toxin used was one always fatal to guinea-pigs in six to eight hours. It would have occasioned no surprise had antitoxin failed to protect, since at best we had only hoped to approximate the toxic colloid in our artificial mxtures, but the experiments while they have not been 
carried on to the extent one would desire seem clearly to indicate a protective influence, specific or otherwise, but proportionate to dosage, on the part of the antitoxin.

Further observations upon the production of artificial toxin mixtures have suggested the availability of emulsifying substances other than proteins, such, for instance, as the dyes, of which Congo red has thus far alone been tried. This question is of interest in connection with the coloring matter of broths noted earlier.

\section{B. MEGATHERIUM. THE ANTIGEN}

The strains of $B$. megatherium were two in number, one of our own, and that known as No. 7 kindly sent us from the Museum of Natural History, the latter having been used and commended by Rous, Robertson and Oliver. ${ }^{12}$

Heavy cultures of the organism were grown for twenty-four to thirty-six hours at $35^{\circ} \mathrm{C}$. in Roux flasks on beef-peptone 1 per cent agar, the mass removed in small amounts of water and saponified in the manner previously described. The collected fatty acid complex was then examined and found to consist of approximately 56 per cent of insoluble unsaturated fatty acid and 44 per cent of volatile fatty acid. The saturated fraction obtained by steam distillation had a melting point of $30^{\circ} \mathrm{C}$. a neutralization value of $233 \mathrm{mgm}$. NaOH, and a calculated M.W. of 175 , showing that it probably consisted wholly of capric acid. The insoluble residue from the distillation, after conversion into the $\mathrm{Pb}$ salts and extraction with ether, showed the absence of further saturated acids, and the fluid acid obtained by conversion of the $\mathrm{Pb}$ salts gave an I.V. of 90 , a neutralization value of $142 \mathrm{mgm}$. $\mathrm{NaOH}$ and a calculated M.W. of 283, data quite in agreement with an oleic acid. The tentative formula for the Megatherium antigen, then, consisted of oleic acid 56 per cent and capric acid 44 per cent. This was different from any previous complex studied but resembled in physical characters most closely that for $B$. anthracis.

12 Jour. Exp. Med., 1919, 29, 283. 
The antigen in the form of the $\mathrm{Na}$ salts with cholesterol was then tested for complement fixing power with the serums of rabbits immunized with washed Megatherium organisms, and with Megatherium hemotoxin. The procedure in this experiment was identical with that used in testing the Diphtheria antigen. The results appear in table 7.

TABLE 7

\begin{tabular}{|c|c|c|}
\hline \multirow{2}{*}{ SERUMS } & \multicolumn{2}{|c|}{ ANTIGENS } \\
\hline & $\begin{array}{l}\text { Control germ } \\
\text { suspension }\end{array}$ & $\begin{array}{c}\text { Artificial fat } \\
\text { antigen }\end{array}$ \\
\hline 1. Rabbit injected, organisms......... & ++ & $+t$ \\
\hline 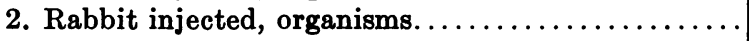 & ++ & ++ \\
\hline 3. Rabbit injected, toxin $\ldots \ldots \ldots \ldots \ldots \ldots \ldots$ & ++ & ++ \\
\hline 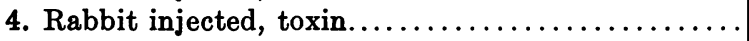 & ++ & ++ \\
\hline 5. Rabbit injected, toxin $\ldots \ldots \ldots \ldots \ldots \ldots \ldots \ldots$ & ++ & ++ \\
\hline 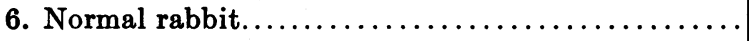 & + & + \\
\hline 7. Normal..................... & - & - \\
\hline 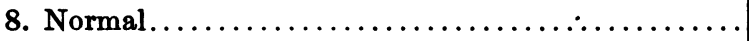 & $+t$ & $+t$ \\
\hline 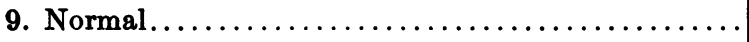 & - & - \\
\hline 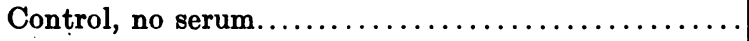 & - & - \\
\hline
\end{tabular}

$++=$ no hemolysis, complete inhibition; $+=$ partial hemolysis; $-=$ complete hemolysis, no inhibition.

Table 8 shows the results of the agglutination-precipitation tests of the same serums with the artificial fat antigen.

\section{TABLE 8}

Each tube contained: Antigen solution 0.08 cc., serum 0.2 cc. and salt solution 1 cc. The tubes after mixing and shaking were placed in the ice box over night and read the following morning.

\begin{tabular}{c|c|c}
\hline SERUM NUMBER & ACTIVE GERUM & INACTIVATED GERUM \\
\hline 1 & + & + \\
2 & + & + \\
3 & + & + \\
4 & + & + \\
5 & + & + \\
6 & + & - \\
7 & - & - \\
8 & - & + \\
\hline
\end{tabular}

$+=$ precipitation; $-=$ cloudy, no precipitation. 
Table 9 shows the results of the precipitation test with the same serums.

TABLE 9

Antigen No. 1. True Megatherium toxin broth.

Antigen No. 2. Artificial toxin broth, composed of 40 cc. broth containing 5 mgm. of Typhoid protein and $2.4 \mathrm{mgm}$. of the $\mathrm{K}$ salts of the Megatherium antigen.

Each tube contained 0.5 cc. of antigen and 0.04 cc. of diluted serum. Readings taken as in table 7 .

\begin{tabular}{c|c|c|c|c}
\hline \multirow{2}{*}{ SERUM NUMBER } & \multicolumn{2}{|c|}{ SERUMS DILUTED 1:60 } & \multicolumn{2}{c}{ SERUMS DILUTED 1:120 } \\
\cline { 2 - 5 } & $\begin{array}{c}\text { (1) } \\
\text { Toxin }\end{array}$ & Artificial toxin & $\begin{array}{c}(1) \\
\text { Toxin }\end{array}$ & Artificial toxin \\
\hline 1 & ++ & + & ++ & + \\
2 & ++ & + & ++ & + \\
3 & ++ & + & ++ & + \\
4 & ++ & + & ++ & + \\
5 & ++ & + & ++ & + \\
6 & - & - & - & - \\
7 & - & - & - & - \\
8 & - & - & - & - \\
Antigen only & - & - & - & - \\
\hline
\end{tabular}

These experiments showed that in all probability the artificial antigen was approximately correct. We observed in these and in later tests that many normal rabbits have natural antibodies against the $B$. megatherium and its toxin. This fact was noted by Todd. ${ }^{13}$

In order to test further the antigenic action of the artificial fat complex, rabbits were immunized by divided S.Q. injections of $0.5 \mathrm{mgm}$. doses emulsified both in broth and in salt solution. Eight days after the sixth and last injection the rabbits were bled and the serums separated and inactivated at $56^{\circ} \mathrm{C}$. for thirty minutes. The following table shows the results of complement fixation carried out in the manner previously described.

From these experiments it appeared that the serums of rabbits immunized with the artificial antigen of $B$. megatherium contained agglutinating and complement fixing antibodies in fair amount together with strong antilysins. Connell had pre-

${ }^{13}$ Lancet, 1901, 2, 1663; Trans. Path. Soc. Lond., 1902, 53, 196. 
TABLE 10

\begin{tabular}{|c|c|c|}
\hline \multirow[b]{2}{*}{ SERUMS } & \multicolumn{2}{|c|}{ ANTIGENS } \\
\hline & $\begin{array}{l}\text { Megatherium } \\
\text { suspension in } \\
\text { salt solution }\end{array}$ & $\begin{array}{l}\text { Artificial } \\
\text { antigen }\end{array}$ \\
\hline 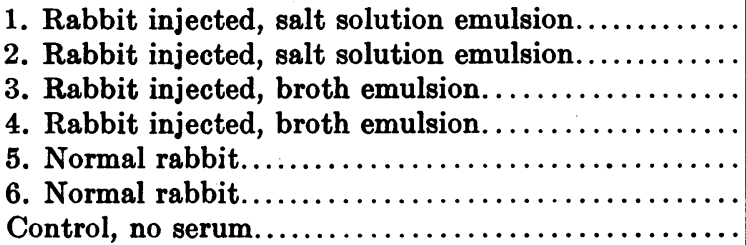 & $\begin{array}{l}++ \\
++ \\
+ \\
+ \\
\pm \\
\pm \\
-\end{array}$ & $\begin{array}{l}++ \\
++ \\
+ \\
+ \\
- \\
-\end{array}$ \\
\hline
\end{tabular}

TABIE 11

The same serum agglutinated a suspension of washed Megatherium in salt solution

Each tube contained: Salt solution suspension 1 cc. and 0.04 cc. serum. Temperature $4^{\circ} \mathrm{C}$. for two hours.

\begin{tabular}{c|c}
\hline SERUMs & suspension \\
\hline 1 & + \\
2 & + \\
3 & +++ \\
4 & ++ \\
5 & - \\
6 & - \\
Control, no serum & - \\
\hline
\end{tabular}

$+++=$ complete agglutination and precipitation; $++=$ almost complete agglutination; $+=$ partial agglutination; $-=$ no agglutination.

TABLE 12

Showing the presence of antihemolysis in the same serums which were tested against . the clear centrifugated lysin of a twenty-four hour veal-Bacto peptone 1 per cent broth culture of which 0.5 cc. caused complete hemolysis of 1 cc. of a 2 per cent suspension of rabbit red cells in salt solution in eight minutes at $97^{\circ} \mathrm{C}$.

Each tube contained: $0.5 \mathrm{cc}$. of fresh hemolysin, $1 \mathrm{cc}$. of cell suspension and 0.04 cc. of serum. The tubes were shaken and placed in a water bath at $37^{\circ} \mathrm{C}$. for two hours, and then allowed to stand at $20^{\circ} \mathrm{C}$. over night.

\begin{tabular}{c|c|c}
\hline SERUMG & 0.04 CC. OF ACTIVE GERUM & $\begin{array}{c}\text { 0.04 CC. OF INACTIE GERUM } \\
\text { DILUTED 1/5 WITH SALT GOLUTION }\end{array}$ \\
\hline 1 & - & - \\
2 & - & - \\
3 & - & - \\
4 & - & ++ \\
5 & ++ & ++ \\
6 & ++ & \\
No serum & ++ &
\end{tabular}

$-=$ no hemolysis; $++=$ complete hemolysis. 
viously shown that the serums of rabbits immunized with Megatherium organisms and with toxin contained strong agglutinins and precipitins. The Megatherium antibodies diminish fairly rapidly in the serums of rabbits after having reached their maximum. This fact was shown by repeated experiments upon the antihemolytic power of the serums from both the series of animals immunized with germ bodies and toxin, and with the artificial antigen, they having been bled two days and again four days after the first drawing. The subsidence in antibody titer was shown to be parallel in the two series.

TABLE 13

Shows the hemolytic and toxic power of our strain of $B$. megatherium

Toxin no. 1: Twenty-four hour broth culture (composition given above) centrifugated clear at high speed, of which 0.04 cc. hemolyzied 1 cc. of 2 per cent red cell suspension in twenty minutes.

Toxin no. 2: Six day broth culture, centrifugated clear. 1 cc. hemolyzed 1 cc. of red cell suspension in thirty minutes.

\begin{tabular}{|c|c|c|c|}
\hline $\begin{array}{c}\text { GUINEA } \\
\text { PIG NUM- } \\
\text { BER }\end{array}$ & \begin{tabular}{|} 
AMOENT IN- \\
JECTED IN- \\
TROPERI- \\
TONEALLY
\end{tabular} & $\begin{array}{c}\text { TOXIN } \\
\text { NUMBER }\end{array}$ & RESULTS \\
\hline 1 & 2 & 1 & Died in less than 12 hours \\
\hline 2 & 2 & 1 & Died in less than 12 hours \\
\hline 3 & 2 & 2 & Died in less than 12 hours \\
\hline 4 & 2 & 2 & Died in less than 12 hours \\
\hline
\end{tabular}

Autopsies showed: Abdomen distended; peritoneum bright red, cavity containing hemolyzed blood; small intestines hemorrhagic with hemorrhages into the lumen; lungs slightly injected; bloody fluid in pleural sacs; heart muscle injected; bloody transudate over thighs.

Guinea-pigs nos. 1 and 2 showed much more intense signs than nos. 3 and 4.

This experiment indicated that both the hemolytic and toxic powers of twenty-four hour cultures of the strain were greater than those of the six day cultures and that, hemolysin and toxin were probably the same substance. 


\section{DISCUSSION}

We believe with Bordet, ${ }^{14}$ Todd, ${ }^{15}$ Craw, ${ }^{16}$ and many others whose work our observations tend to confirm that hemolysins are true toxins. Some toxins may not be hemolytic for the reason that the toxic particle may be of a size which does not readily form adsorption aggregates with red cells, or because of the protective action of proteins or other emulsifying substances. All antigens so far examined are hemolytic in certain colloidal states.

We have brought considerable evidence to show that the toxins of $C$. diphtheriae and of $B$. megatherium probably consist of the respective fat antigens of the organisms existing in definite colloidal states, the particulate nature of the complexes being an indispensible factor. As will be stated in greater detail in another paper the particulate character of all antigens is necessary to the colloidal concept of immune processes. Just as bacteria, parasitic in the blood and tissues of an animal, are colloidal particles having specific and characteristic surface chemistry, so also are the artificial fat antigens which have been used as substitutes for the germ bodies. The mode of action of such colloids is twofold, the primary one being that of "surface," or particles, alone, the secondary one that of the specific chemistry of the particles regulating the specificity of the immune response. The injection of unorganized particulate surface (kaolin, charcoal) leads to adsorptions and induced toxicity of the plasma of the animal (anaphylaxis); injections of, or infection by, bacteria or other cells also produce adsorptions, but the character of the substances adsorbed must be different for each species of cell, depending on the chemical complex constituting its surface.

The result of such adsorptions on the body fluids is a deprivation of some of their constituents, followed by the fluids compensating, or making good their loss by an attack upon certain

14 Bordet-Gay, Studies in Immunity, 1909, p. 186. et seq.

${ }^{16}$ Loc. cit.

${ }^{16}$ Proc. Roy. Soc. Lond., Ser. B., 1905, 76, 179. 
groups of body cells which may contain the missing substances upon their surfaces. There is considerable evidence pointing to the fact that toxins and antigens need not act directly on the cells but through the medium of the fluids bathing them. The substances primarily adsorbed, when regained gradually and in excess from the cells we regard as specific antibody.

The specific fat antigen complex of a cell may be one which in its particulate character may produce poor or ready response on the part of the body fluids, the result being inferior or strong antibody, as for instance Streptococcus and V. cholerae; while on the other hand the definite colloidal size of the antigen particle may be necessary to powerful antibody production, for example the $C$. diphtheriae; and again the colloidal dispersion of the antigen may be variable and still yield all antibodies from the agglutinins at one extreme to antitoxin at the other, as with the $B$. megatherium. It is conceivable also that the fluids and cells of the body respond better to some fat complexes than to others, irrespective of colloidal arrangement. At best poor antibodies result from attempted immunizations of laboratory animals with the bodies of streptococci, and the same is true with the artificial antigen and with the true streptococcus hemolysin, but considering the extraordinary colloidal richness of mammalian fluids and cells this idea does not seem so tangible as another which is, briefly, that the antigenic complexes of these microörganisms have not up to the present been employed in a proper colloidal form, and we are inclined to think that further study on the fluid media in which the bacteria are grown will throw light on the obscure problem.

A necessary corollary to these principles is that all antigenantibody reactions, from agglutination and precipitation through complement fixation to toxin-antitoxin aggregates, are but phases of the same phenomenon acting from one extreme of the colloidal realm to the other, and that all phases must be possible with all cell antigens if only the proper colloidal state can be found. Dean ${ }^{17}$ showed that complement fixation and precipi-

${ }^{17}$ Lancet, 1918. 1, 45. 
tation are phases of the same reaction, and J. Alexander ${ }^{18}$ has seen the diphtheria toxin-antitoxin union by ultramicroscopic methods.

It will be observed that no mention has been made of the so-called "lipoids." These substances play no part in the phenomenon whatever. The term "fat" has been given a somewhat elastic use to include the fatty acids and their salts and esters. Cholesterol is not a lipoid but an alcohol. The writers are of opinion that the evidence for the existence of hard and fast lipoid substances such as lecithin and kindred bodies, as such, in the fluids and cells of the body is very unsatisfactory and doubtful. The mere fact that they may be extracted from dried tissues by certain solvents does not signify at all that they existed as entities therein. There are as many kinds of lecithin as there are kinds of tissue, and, on the other hand, Barbieri and his pupils ${ }^{19}$ failed to find a trace of lecithin in 3000 eggs. The availability of, if not the necessity for, delicate, easily shifted, labile adsorption compounds of electrolyte-fat-protein within the body fluids is, however, undisputed, and it is probable that the whole mechanism of immunity occurs in just such emulsion colloids. The proper emulsification of bacterial and their artificial antigens with emulsifying agents is regarded as the sine qua non of toxin production. The rôle of cellular protein aside from some such action does not appear to be paramount and is not otherwise essential to antibody formation. The "type" antibody response to protein and the "specific" antibody response to cells are but phases of the same process. Fatfree protein, having no fat at its surface, has nevertheless chemical configuration and particulate size, factors assuring adsorptions and antibody production, and the antibodies respond clearly to the antigen "type" only, lacking the sharp specificity of cellular antibody for the very reason of the fat-free character of the antigen.

The similar behavior of true and artificial lysins and toxins in relation to heat, $\mathrm{pH}$, reagents, adsorbents, effects on animals, etc.,

${ }^{18}$ Bechhold-Bullawa, footnote, p. 195.

${ }^{19}$ Gazzetta, 1917, 47, 1. 
has been brought out in the paper of Connell and Holly "On the Nature of Hemolysin."

We believe there has been adduced fair evidence warranting the following tentative conclusions:

1. The $C$. diphtheriae and $B$. megatherium possess characteristic fat complexes which are, under proper colloidal conditions, the true antigens of these microörganisms. Artificial fat antigens have replaced the antigens of the germ bodies in the various immune reactions.

2. The lysins and toxins of the $C$. diphtheriae and the $B$. megatherium are the same substances, being, respectively, the specific fat antigens of the microörganisms existing in definite and particular colloidal states.

3. Aside from colloidal or emulsifying activity cellular protein appears to have no place in the immune reactions studied. 